\title{
Studies on Sedum taxa found in Sicily (Italy) for Mediterranean extensive green roofs
}

\author{
Teresa Tuttolomondo, ${ }^{1}$ Giancarlo Fascella, ${ }^{2}$ Mario Licata, ${ }^{1}$ Rosario Schicchi, ${ }^{1}$ \\ Maria Cristina Gennaro, ${ }^{1}$ Salvatore La Bella, ${ }^{1}$ Claudio Leto, ${ }^{1}$ Simona Aprile ${ }^{2}$ \\ ${ }^{1}$ Department of Agricultural, Food and Forest Sciences, Università degli Studi di Palermo, Palermo; ${ }^{2}$ CREA \\ Research Centre for Plant Protection and Certification, Bagheria (PA), Italy
}

\begin{abstract}
One type of green roof whose function is ecological and environmental rather than aesthetic is the extensive green roof. Many studies have shown that Sedum performs very well compared to other hardy species in substrates of less than $10 \mathrm{~cm}$. It seems that Sedum species are able to survive in very thin substrates; they tolerate extreme temperatures and sudden variations in temperatures, high levels of solar radiation, strong winds, poor substrate fertility and extreme drought. In particular, this paper looks at the potential of a number of species from the Sicilian taxa of the genus Sedum (Crassulaceae), which are considered to be those xerophytes most suited for use in extensive green roof systems for Mediterranean areas. Each taxon was subject to in situ and ex situ observations to gain phenological and ecological data, information on its vegetative propagation capacity and its plant ground cover capacity. The results of this study have led to greater understanding of Sicilian pluriennal Sedum genus entities of potential use in green roof systems in the Mediterranean. The taxa respond particularly well to agamic propagation, showing characteristics suited to nursery production of green roof systems, with the exception of $S$. amplexicaule subsp. tenuifolium. Growth indices and plant development (ground cover) demonstrated the capacity of a number of Sedum taxa to form a uniform green mantle over time. S. sediforme and S. album subsp. album. showed interesting results, for because of their ability to colonize the substrate, and they could be fundamental in determining the plant structure of the green systems.
\end{abstract}

Correspondence: Salvatore La Bella, Department of Agricultural, Food and Forest Sciences, Università degli Studi di Palermo, viale delle Scienze 13, Edificio 4, 90128 Palermo, Italy.

E-mail: salvatore.labella@unipa.it

Key words: Green roofs; Sedum; Mediterranean environment.

Received for publication: 1 August 2017.

Revision received: 21 October 2017.

Accepted for publication: 23 October 2017

(C) Copyright T. Tuttolomondo et al., 2018

Licensee PAGEPress, Italy

Italian Journal of Agronomy 2018; 13:1077

doi:10.4081/ija.2018.1077

This article is distributed under the terms of the Creative Commons Attribution Noncommercial License (by-nc 4.0) which permits any noncommercial use, distribution, and reproduction in any medium, provided the original author(s) and source are credited.
However, there are also other plants, such as $S$. amplexicaule var. tenuifolium, and, to a lesser extent, $S$. dasyphyllum var. dasyphyllum and S. ochroleucum, which are able to contribute to floral diversification and lead to greater biodiversity in the system. These taxa could be used when creating associations of Sedum at lower percentages compared to the structuring species $(\leq 20 \%)$.

\section{Introduction}

Green roofs go back an extremely long way in history: the Hanging Gardens of Babylon are a famous example, but we might also mention Scandinavian sod roofs or the garden roofs on Roman villas (Osmundson, 1999; Grant et al., 2003). In ensuing ages, green roofs and living walls fell into disuse, only to reappear during the $19^{\text {th }}$ century following increased urbanization. In recent years, due to even greater urban development, losses in green areas and the resulting environmental problems, green roofs are enjoying renewed attention, as proposed by Benedict and Mcmahon (2002), as an effective tool in climate change adaptation (Liptan, 2003; Carter, 2011). Green roofs contribute towards restoring our urban environment to the former ecological operational level, which it enjoyed before urbanization (Palla et al., 2010). Green roofs are able to reduce not only the thermal load of a building (Niachou et al., 2001), the urban heat island effect (Dimoudi and Nikolopoulou, 2003; Wong et al., 2003), and air/water pollution levels (Liesecke and Borgwardt, 1997), but also the amount of stormwater runoff from the roof (Liesecke, 1998; Mentens et al., 2003; Monterusso et al., 2005; Van Woert et al., 2005). Furthermore, Relf and Lohr (2003) mention numerous studies highlighting the positive effects that plants have on our well-being and on stress reduction. One type of green roof whose function is ecological and environmental rather than aesthetic is the extensive green roof. Originating in Germany, studies on this type of green roof already demonstrated as early as 1950-1960 the survival capacity of certain Sedum species on gravel-bed roofs, as reported by Herman (2003). The use of this plant genus in extensive green roofs spread widely not only in Germany but also throughout Europe. The genus Sedum (Crassulaceae), due to its eco-physiological characteristics, is well adapted to grow on poor substrates and show a good drought tolerance (Monterusso et al., 2005; VanWoert et al., 2005; Rowe et al., 2006). Several species of genus Sedum are characterized by crassulacean acid metabolism (Kluge, 1977; Terri et al., 1986; Gravatt and Martin, 1992; Lee et al., 1994; Sayed et al., 1994; Gravatt, 2003) which is a carbon fixing metabolic cycle that optimizes the photosynthetic activity in extreme environments, such as desert environments, ensuring photosynthesis also with closed stomata. This represents a xerophytic adaptation of plants because, being the stomata 
closed during the day, transpiration and water consumption in plant tissues can decrease (Cushman, 2001), therefore it is possible to achieve a water use efficiency three or five times more than that of the C3 plants (Kluge and Ting, 1978). Other studies (Heinz, 1985; Gomez-Campo, 1994; Gomez-Campo and Gomez-Tortosa, 1996; Lassalle, 1998; Boivin et al., 2001) have shown that Sedum performs very well compared to other hardy species in substrates of less than $10 \mathrm{~cm}$. It seems that Sedum species are able to survive in very thin substrates; they tolerate extreme temperatures and sudden variations in temperatures, high levels of solar radiation, strong winds, poor substrate fertility and extreme drought. The genus Sedum includes over 500 species, mostly distributed across the temperate and subtropical regions of the Northern Hemisphere (Hart, 1991). Some species are native to Mexico or Central America but are also found widely in North Africa. Throughout the entire Northern Hemisphere there are approx. 140 accessions of Sedum. In the west of the Mediterranean, most species are found in the Iberian Peninsula, whereas in the east, they are most widespread in the Balkans. Italy has 43 taxa with 30 native species and 13 subspecies (Conti et al., 2005), which grow mostly in coastal and mountainous rocky areas but also in anthropized environments. Many species are grown for ornamental purposes and used in rock gardens or pots. In Sicily, the genus Sedum contains 19 taxa: 10 perennial and 9 annual taxa (Raimondo et al., 2010). Entities are also widespread in Mediterranean and Eurosiberian regions, stretching from North Africa to Central and Eastern Europe and islands. Most Sicilian species are succulent, evergreen chamaephytes [Sedum acre L. subsp. acre, Sedum acre subsp. neglectum (Ten.) Arcang., Sedum album L. subsp. album, Sedum album subsp. micranthum (DC.) Syme, Sedum dasyphyllum L. var. dasyphyllum, Sedum dasyphyllum var. glanduliferum (Guss.) Moris, Sedum gypsicola Boiss. \& Reut., Sedum ochroleucum Chaix., Sedum sediforme (Jacq.) Pau]; only one is deciduous $[S$. amplexicaule subsp. tenuifolium (Sm.) Greuter]. The plants belonging to these species are low-growing, bushy shrubs which grow to a height of between $15-40 \mathrm{~cm}$. These subshrubs complete their growth stages from mid-winter through to the spring, when flowering begins. Only few species flower into the summer months. Annual species include: Sedum aetnense Tineo, Sedum caeruleum L., Sedum caespitosum (Cav.) DC., Sedum cepaea L., Sedum litoreum Guss., Sedum rubens L. var. rubens, Sedum rubens var. cosyrensis Sommier, Sedum stellatum L. These species also include Sedum hispanicum L. which, in Mediterranean environments, behaves as a biennial or perennial. Annual Sedum species are found with upward growing or dense branches and grow to a height of 3-20 cm. Plants belonging to the Sedum genus generally grow in lithosols and regosols with a calcareous, dolomitic, chalky-sulphurous, sandstone and volcanic substrate. They are pioneer species, colonizing rocky outcrops, where they become part of the rock plant community, and sinantropic environments, such as old walls, building debris and derelict buildings. Currently in Italy, examples of green roofs for energy-saving purposes are mostly seen only in the north. There are only a few isolated cases in the south of Italy in multinational company offices or representation offices; green roof systems are mostly developed or patented in non-Mediterranean environments and installation costs are still high (Abram, 2006). A number of studies (Fioretti et al., 2010; Zinzi and Agnoli, 2012; Van Mechelen et al., 2014) contribute to furthering technical and numerical data (coefficients, correction factors, indices, etc.) in the design of extensive green roof systems in the Mediterranean, with a particular focus on the depth of the water retention layer, the drainage system and the plant layer. Regarding this latter aspect, this paper seeks to identify wild plant species, which are suitable for use in green roof systems in the Mediterranean. In particular, this paper looks at the potential of a number of species from the Sicilian taxa of the genus Sedum (Crassulaceae), which are considered to be those xerophytes most suited for use in green roof systems (Boivin et al., 2001; Lassalle, 1998; Monterusso et al., 2005).

\section{Materials and methods}

The study takes into consideration a number of Sicilian taxa of the genus Sedum, which were considered as representatives of Sicilian region. Their identification was made using the key Flora d'Italia (Pignatti, 1982) whilst their nomenclature was based on Raimondo et al. (2010): S. album L. subsp. album, S. amplexicaule subsp. tenuifolium (Sm.) Greuter, S. caeruleum L., S. gypsicola Boiss. \& Reut., S. hispanicum L., S. dasyphyllum var. dasyphyllum, S. dasyphyllum var. glanduliferum (Guss.) Moris, S. litoreum Guss., S. ochroleucum Chaix, S. rubens L. var. rubens, S. stellatum L. and $S$. sediforme (Jacq.) Pau. In situ observations were carried out for each taxa while ex situ observations were made for a few taxa only. These taxa were $S$. album L. subsp. album, S. amplexicaule subsp. tenuifolium (Sm.) Greuter, S. dasyphyllum var. dasyphyllum, S. gypsicola Boiss. \& Reut., S. hispanicum L., S. sediforme (Jacq.) Pau, S. ochroleucum Chaix. They were selected on the basis of the plant material availability and their habitus considered more suitable for the aim of the study.

\section{In situ observations}

Based on information found in literature (Troìa et al., 1998; Raimondo et al., 2010), in February 2010, a number of collection sites were selected in Sicily in order to carry out ecological and phenological observations on the taxa and for germplasm sampling. A representative sample of the population, consisting of 1020 individuals, was observed at each site, individual plants were selected randomly and the ecological characteristics of the site (type of substrate and habitat) and phenological characteristics of the taxa (vegetative stage, flowering period, seed ripening) were noted. Observations of each taxon were made on six occasions during the year from spring to autumn. All data were transferred to a database for elaboration. During spring and autumn, germplasm collection (plant stems, bushes) was carried out for ex situ research activity and in order to conserve wild germplasm of Sedum at CREA Research Center for Plant Protection and Certification in Bagheria (Italy) (38 $5^{\prime} \mathrm{N}-13^{\circ} 30^{\prime} \mathrm{E}, 23 \mathrm{~m}$ a.s.1.) Particularly, each taxon was identified using voucher specimen codes (from S12 to $\mathrm{S} 23)$. The taxa were placed in a open field collection at the CREA Research Center.

\section{Ex situ observations}

In the spring 2010, of the Sedum taxa planted in the open field collection at the CREA Research Center in Bagheria, only $S$. album L. subsp. album, S. amplexicaule subsp. tenuifolium (Sm.) Greuter, S. dasyphyllum var. dasyphyllum, S. gypsicola Boiss. \& Reut., S. hispanicum L., S. sediforme (Jacq.) Pau and S. ochroleucum Chaix, were considered for research activities in order to evaluate the rooting capacity, growth index and plant ground cover.

\section{Rainfall and temperature trends}

During the test period, rainfall and temperatures trends were recorded using a Stevenson screen that was located at the CREA Research Center in Bagheria. This town is located in the north 
coast of Sicily in province of Palermo city. The climate of Bagheria is characterized by mild winter and warm and drought summer and can be considered as representative of the Mediterranean coastal areas for which this study was aimed.

\section{Rooting capacity}

Cuttings 4-5 $\mathrm{cm}$ in length with a base diameter of approx. 0.3 $\mathrm{cm}$ were obtained from the samples. These were then placed in a protected environment held at an average temperature of $22^{\circ} \mathrm{C}$ and relative humidity below $40 \%$, in order to obtain partial tissue dehydration. After 7 days, the cuttings were planted to begin rooting in polystyrene trays. Substrate was composed by a mix of potting soil (COMPO SANA ${ }^{\circledR}$ - Cesano Maderno, MB, Italy), silica river sand and expanded perlite of 2-6 mm (PERLITE ITALIANA - Corsico, MI, Italy) $(1: 0,5: 1 ; \mathrm{v} / \mathrm{v} / \mathrm{v})$ without the use of rooting hormone. The trays were placed on a cement bench cover with a double layer of nonwoven fabric and transparent PE. The bench was equipped with a mist system in order to maintain humidity levels between $40-50 \%$. Nursery trays were placed inside an unheated greenhouse covered by polymethacrylate methyl glass and shaded by netting to obtain $50 \%$ light intensity reduction. A completely randomized plot design was adopted; each species was replicated 3 times, each replication containing 25 cuttings. Rooting percentage of the different species was determined between the $15^{\text {th }}$ and $30^{\text {th }}$ day following planting: a cutting was considered rooted if it had emitted a root, which exceeded $0.3 \mathrm{~cm}$ in length.

\section{Growth index}

The rooted Sedum cuttings were placed into transplanted into polystyrene pots of $0.5 \mathrm{~m}^{2}$, at a planting density of 30 cuttings $/ \mathrm{m}^{2}$, and positioned outside. The substrate used for this stage was a mix of potting soil (COMPO SANA® - Cesano Maderno, MB, Italy), silica river sand and red soil $(1: 1: 0.5 ; \mathrm{v} / \mathrm{v} / \mathrm{v})$. Water was supplied at planting time only at a rate of $3 \mathrm{~L} / \mathrm{m}^{2}$ using a graduated container, in order to obtain the plant rooting. The growth index (GI) was used as a quantitative indicator when comparing plant sizes of the various Sedum species. As reported by Monterusso et al. (2005) and Schaefer et al. (2005), growth index was calculated using the following equation $\left(\mathrm{H}+\mathrm{W}_{1}+\mathrm{W}_{2}\right) / 3$ where: $\mathrm{H}$ is the plant height; $\mathrm{W}_{1}$ is the transversal diameter of the plant; $\mathrm{W}_{2}$ is the longitudinal diameter of the plant. These parameters were recorded 30 days after the rooted cuttings were planted up to 120 days at subsequent 30 -day intervals. A completely randomized plot design was adopted; each species was replicated 3 times, each replication containing 15 plantlets.

\section{Plant ground cover growth}

The plant ground cover growth was measured as a plant horizontal growth indicator. Assimilating each plant to a circle, the radius was then taken in order to calculate the surface area of each plant (Razzaghmanesh et al., 2014). A completely randomized plot design was adopted; each species was replicated 3 times and each replication contained 25 plantlets.

\section{Statistical analysis}

Analysis of variance (one-way ANOVA) was carried out on the test data using the statistical software Past (V. 3.16 for Windows). Means for each taxon ( $\pm \mathrm{SE}$ ) were separated using Tukey test. Rooting rates for the various species were analysed using arc sine transformation (Gomez and Gomez, 1984) prior to analysis of variance.

\section{Results and discussion}

\section{Rainfall and temperature trends}

Rainfall and temperature trends (Figure 1) observed over the test period showed average temperatures of $18.3^{\circ} \mathrm{C}$ and total rainfall (November 2010 to February 2011) of $137.2 \mathrm{~mm}$. Data would seem to be consistent with seasonal averages in the area, characterized by mild winters and rainfall mostly concentrated in the autumn-winter seasons; minimum temperatures never dropped below $5^{\circ} \mathrm{C}$ whilst maximum temperatures were recorded around early November, with a peak of $23^{\circ} \mathrm{C}$. Approximately $60 \%$ of total rainfall was recorded in February, above all in the first 20 days.

\section{In situ observations}

Studies carried out at the various stations, together with a bibliographic study, allowed us to gather ecological and phenological data on the Sicilian Sedum genus taxa, shown in summary form in Table 1. The table lists the sampling stations for each of the taxa in the study, their habitat and the periods relating to the vegetative and reproductive stages (initial flowering-seed ripening). The sampling stations were located both in coastal areas (Capo Zafferano, Solunto, Marettimo, Torre Salsa and Monte Catalfano) and hilly and mountain areas (Monte Quacella, Gratteri, Rocca di Entella, Isnello and Collesano). Most of the taxon were found growing in carbonate lithosols and regosols, generally quite thin, typical of the west of Sicily, where the plants are able to thrive even on rocky outcrops. S. gypsicola and S. ochroleucum, however, are found growing on crystalline substrates of Gessoso-Solfifera formation. The Sedum sampling stations also gave information on the syntaxon typically found in Sicily. The Sedo-Scleranthetea Br.-B1. 1955 class was common; widespread in Western Mediterranean areas in carbonate arid soils. This class includes $S$. album, S. amplexicaule, $S$. gypsicola and $S$. sediforme together with other rock and camephytic entities and other Sedum species ( $S$. caeruleum, S. rubens, etc.). The Stipo-Trachynietea distachyae Brullo 1985 class, typical of rocky outcrops and little-evolved, thin soils, includes a number of Sedum species, from sea level (S. litoreum) to hilly, piedmont areas ( $S$. caeruleum and $S$. rubens), together with other thermoxerophytic shrubs (comprising a number of annual ephemerals).

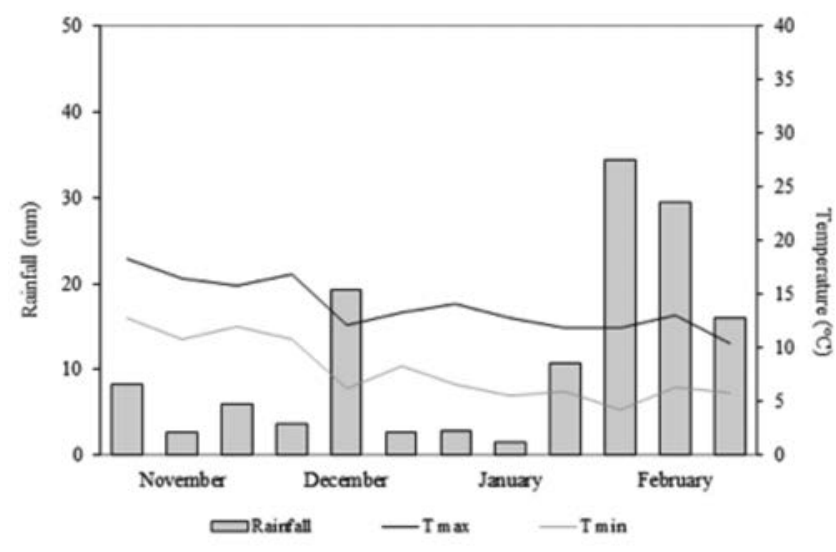

Figure 1. Rainfall and temperature trends (Bagheria, November 2010-February 2011). 
Sedum hispanicum gathered from the Isnello station (PA), belongs to the Tuberarietea guttatae Br.-Bl. in Br.-Bl., Roussine et Nègre 1952 em. de Foucault 1999 class, together with other therophytic vegetation, often ephemeral and highly xerophytic. Sedum dasyphyllum var. dasyphyllum and S. dasyphyllum var. glanduliferum belong to the Parietarietea judaicae Oberdorfer 1977 class, characterized by communities of herbaceous perennials, mostly geophytes and hemicryptophytes, mesophiles or sciophytes, typically found in moist, anthropogenic substrates. As can be seen from the same table, the vegetative stage of most species generally occurs in Spring. Exceptions include Sedum caeruleum, which begins vegetative activity from January, and $S$. amplexicaule subsp. tenuifoli$u m$ and $S$. litoreum, which begin vegetative activity between February and March, concluding after two months. Sedum caeruleum is the first species to flower (beginning of March) followed by $\mathrm{S}$. litoreum, $S$. amplexicaule subsp. tenuifolium, $S$. rubens var. rubens and $S$. stellatum, which beginning flowering in April. Sedum rubens appears a little different to the other species as its flowering period lasts for 3 months. The other taxa examined start to flower between May and June, persisting only 1-2 months. Seed ripening is completed approximately two months after flowering.

\section{Rooting capacity}

Results of the agamic propagation, 15 and 30 days from plant- ing of the cuttings, are shown in Table 2. 15 days from planting, $S$. sediforme and $S$. hispanicum showed greatest rooting percentages at $82.4 \%$ and $83.3 \%$ respectively, although statistically significant differences were not found with $S$. album subsp. album (78.4\%), $S$. gypsicola (78.6\%), S. dasyphyllum var. dasyphyllum (79.1\%) and S. ochroleucum $(75.3 \%)$. The lowest rooting percentages was found with S. amplexicaule subsp. tenuifolium (34.5\%), when statistically significant differences were found between taxa. 30 days after planting, the rooting percentages of the cuttings had increased considerably in all of the taxa and the highest value was of $98.7 \%$ for $S$. sediforme and S. album subsp. album. These taxa together with S. gypsicola (93.3\%), S. dasyphyllum var. dasyphyllum (89.3\%), S. ochroleucum (97.3\%) and S. hispanicum (96.0\%) were statistically different from $S$. amplexicaule subsp. tenuifolium that showed the lowest value of rooting capacity (38.7\%).

\section{Growth index}

Figure 2 shows the growth index relative to the Sedum taxa in the study 30 to 120 days from planting. In general, for all the taxa in the study, growth index increased during the observation period and no dormancy stage of the plants was recorded. This was probably due to the favourable climate conditions between November and February with average temperatures of $18.3^{\circ} \mathrm{C}$ and well-distributed rainfall. These conditions contributed to maintain a well moisture level of the plant substrate. However the results of plant

Table 1. Ecological and phenological observations on Sedum genus taxa.

\begin{tabular}{|c|c|c|c|c|c|c|}
\hline Taxon & $\begin{array}{l}\text { Sampling } \\
\text { station }\end{array}$ & $\begin{array}{l}\text { Environment } \\
\text { and substrate }\end{array}$ & Syntaxon & $\begin{array}{l}\text { Vegetative } \\
\text { stage }\end{array}$ & Flowering & $\begin{array}{l}\text { Seed } \\
\text { ripening }\end{array}$ \\
\hline Sedum album L. subsp. album & $\begin{array}{l}\text { Monte Quacella } \\
\text { (Palermo, Italy) }\end{array}$ & $\begin{array}{l}\text { Carbonate lithosols and } \\
\text { regosols, hilly and } \\
\text { mountainious areas }\end{array}$ & Sedo-Scleranthetea & March - May & June-July & August-September \\
\hline $\begin{array}{l}\text { Sedum amplexicaule subsp. } \\
\text { tenuifolium (Sm.) Greuter }\end{array}$ & $\begin{array}{l}\text { Monte Quacella } \\
\text { (Palermo, Italy) }\end{array}$ & $\begin{array}{l}\text { Carbonate substrates in hilly } \\
\text { and mountainous areas }\end{array}$ & Sedo-Scleranthetea & February-March & April-June & August-September \\
\hline Sedum caeruleum $\mathrm{L}$. & $\begin{array}{l}\text { Gratteri } \\
\text { (Palermo, Italy) }\end{array}$ & $\begin{array}{l}\text { Carbonate lithosols in hilly } \\
\text { and piedmont areas }\end{array}$ & $\begin{array}{l}\text { Stipo-Trachynietea } \\
\text { distachyae }\end{array}$ & January-February & February-May & July-August \\
\hline $\begin{array}{l}\text { Sedum gypsicola } \\
\text { Boiss \& Reut. }\end{array}$ & $\begin{array}{l}\text { Rocca di Entella } \\
\text { (Palermo, Italy) }\end{array}$ & $\begin{array}{l}\text { Lithosols and regosols; } \\
\text { Gessoso-Solfifera formation } \\
\text { (abundant gypsum and salt) }\end{array}$ & Sedo-Scleranthetea & March-April & June-August & September-October \\
\hline Sedum hispanicum L. & Isnello (Palermo, Italy) & $\begin{array}{l}\text { Limestone in hilly and } \\
\text { mountainous areas }\end{array}$ & Tuberarietea guttatae & March-April & May-June & July-August \\
\hline $\begin{array}{l}\text { Sedum dayphyllum var. } \\
\text { dasyphyllum }\end{array}$ & $\begin{array}{l}\text { Capo Zafferano } \\
\text { (Palermo, Italy) }\end{array}$ & Carbonate lithosols & Parietarietea judaicae & March-April & May-July & August-September \\
\hline $\begin{array}{l}\text { Sedum dasyphyllum } \\
\text { var. glanduliferum (Guss.) } \\
\text { Moris }\end{array}$ & Solunto (Palermo, Italy) & Carbonate lithosols & Parietarietea judaicae & March-April & May-July & August-September \\
\hline Sedum litoreum Guss. & Marettimo (Trapani, Italy) & $\begin{array}{l}\text { Carbonate substrates } \\
\text { in coastal areas }\end{array}$ & $\begin{array}{l}\text { Stipo-Trachynietea } \\
\text { distachyae }\end{array}$ & February-March & April- May & July-August \\
\hline Sedum ochroleucum Chaix & Torre Salsa (Agrigento, Italy) & $\begin{array}{l}\text { Lithosols and regosols; } \\
\text { Gessoso-Solfifera series } \\
\text { in coastal and hilly areas }\end{array}$ & $\begin{array}{l}\text { Sedion micrantho } \\
\text { sediformis }\end{array}$ & March-April & May-July & August-October \\
\hline Sedum rubens L. var. rubens & Collesano (Palermo, Italy) & $\begin{array}{l}\text { Limestone lithosols } \\
\text { in hilly areas }\end{array}$ & $\begin{array}{l}\text { Stipo-Trachynietea } \\
\text { distachyae }\end{array}$ & February-March & April-July & August-September \\
\hline Sedum stellatum $\mathrm{L}$. & $\begin{array}{l}\text { Monte Catalfano } \\
\text { (Palermo, Italy) }\end{array}$ & $\begin{array}{l}\text { Carbonate regosols in coastal, } \\
\text { hilly and piedmont areas }\end{array}$ & $\begin{array}{l}\text { Geranio-Cardaminetea } \\
\text { hirsutae }\end{array}$ & February-March & April-May & June-August \\
\hline $\begin{array}{l}\text { Sedum sediforme } \\
\text { (Jacq.) Pau }\end{array}$ & $\begin{array}{r}\text { Monte Catalfano } \\
\text { (Palermo, Italy) }\end{array}$ & $\begin{array}{l}\text { Carbonate lithosols and } \\
\text { regosols in coastal, } \\
\text { hilly and piedmont areas }\end{array}$ & Sedo-Scleranthetea & March-April & May -July & August-October \\
\hline
\end{tabular}


growth were different for each taxon. Some of taxa showed a the highest growth while others the lowest. Particularly, it is clear from the graph that $S$. sediforme recorded the highest values $(9.8,30$ days after planting and 15.6, 120 days after planting); these results were statistically different compared to all the other Sedum, in almost the entire test period. S. hyspanicum and S. gypsicola recorded the lowest GI values for the whole test period: $S$. hyspanicum ranged from 5.1 to 9.3 and S. gypsicola from 5.8 to 10.8. The two taxa showed statistical differences between each other and the other taxa. Differences were found to be statistically significant compared to the other taxa. GI results for the species $S$. album, $S$. amplexicaule, S. dasyphyllum var. dasyphyllum and S. ochroleucum were found to be intermediate compared to the abovementioned Sedum throughout the test period. S. album and S. dasyphyllum, in particular, did not show significant differences between the two groups as their GI values were more or less the same. $S$. amplexicaule and S. ochroleucum were shown to have very similar GI values and no statistically significant differences were found between them, in almost the entire test period.

\section{Increase in plant ground cover}

In addition to the plant growth index, this study also analysed average increase in plant ground cover (Figure 3). Results showed that $S$. sediforme performed best over the whole period (from 118 to $300 \mathrm{~cm}^{2}$ ), and showed statistically significant differences compared to all the other Sedum entities. Considering only the initial observations stages, $S$. amplexicaule var. tenuifolium followed $S$. sediforme in ground cover performance results, with a cover of $98.5 \mathrm{~cm}^{2}$ (at 30 days) and $171.4 \mathrm{~cm}^{2}$ (at 90 days); these differences were considered statistically significant compared to the other taxa. However, 120 days from planting, results for ground cover of $S$. album $\left(242.6 \mathrm{~cm}^{2}\right)$ had outperformed $S$. amplexicaule var. tenuifolium $\left(202.3 \mathrm{~cm}^{2}\right)$ and, at the end of the test period, it ranked second behind $S$. sediforme, with significant differences compared to the other taxa. Plant ground cover results for S. gypsicola $(187.5$ $\mathrm{cm}^{2}$ ) and $S$. dasyphyillum var. dasyphyillum $\left(189.1 \mathrm{~cm}^{2}\right)$, by the end of the test period, were lower compared to $S$. amplexicaule var. tenuifolium, with no significant differences found. Up to 90 days from planting, plant cover for S. ochroleucum (87.4-105-143.2 $\mathrm{cm}^{2}$ ) was similar to $S$. dasyphyllum var. dasyphyillum and $S$.

Table 2. Rooting percentages of the various Sedum species in the study.

\begin{tabular}{lll} 
Species & Days from planting (\%) \\
& 15 days & 30 days \\
Sedum album subsp. album & $78.4 \pm 1.2^{\mathrm{a}}$ & $98.7 \pm 1.3^{\mathrm{a}}$ \\
Sedum gypsicola & $78.6 \pm 3.8^{\mathrm{a}}$ & $93.3 \pm 2.6^{\mathrm{a}}$ \\
\hline Sedum dasyphyllum var. dasyphyllum & $79.1 \pm 5.0^{\mathrm{a}}$ & $89.3 \pm 1.3^{\mathrm{a}}$ \\
Sedum sediforme & $82.4 \pm 4.7^{\mathrm{a}}$ & $98.7 \pm 1.3^{\mathrm{a}}$ \\
\hline Sedum amplexicaule subsp. tenuifolium & $34.5 \pm 2.9^{\mathrm{b}}$ & $38.7 \pm 1.3^{\mathrm{b}}$ \\
Sedum ochroleucum & $75.3 \pm 2.6^{\mathrm{a}}$ & $97.3 \pm 2.3^{\mathrm{a}}$ \\
\hline Sedum hispanicum & $83.3 \pm 2.8^{\mathrm{a}}$ & $96.0 \pm 4.0^{\mathrm{a}}$ \\
\hline
\end{tabular}

Values represent the mean \pm standard error. The means $( \pm$ SE) within a column followed by different letters are significantly different at $P \leq 0.01$, according to one-way ANOVA and separated using Tukey's test.

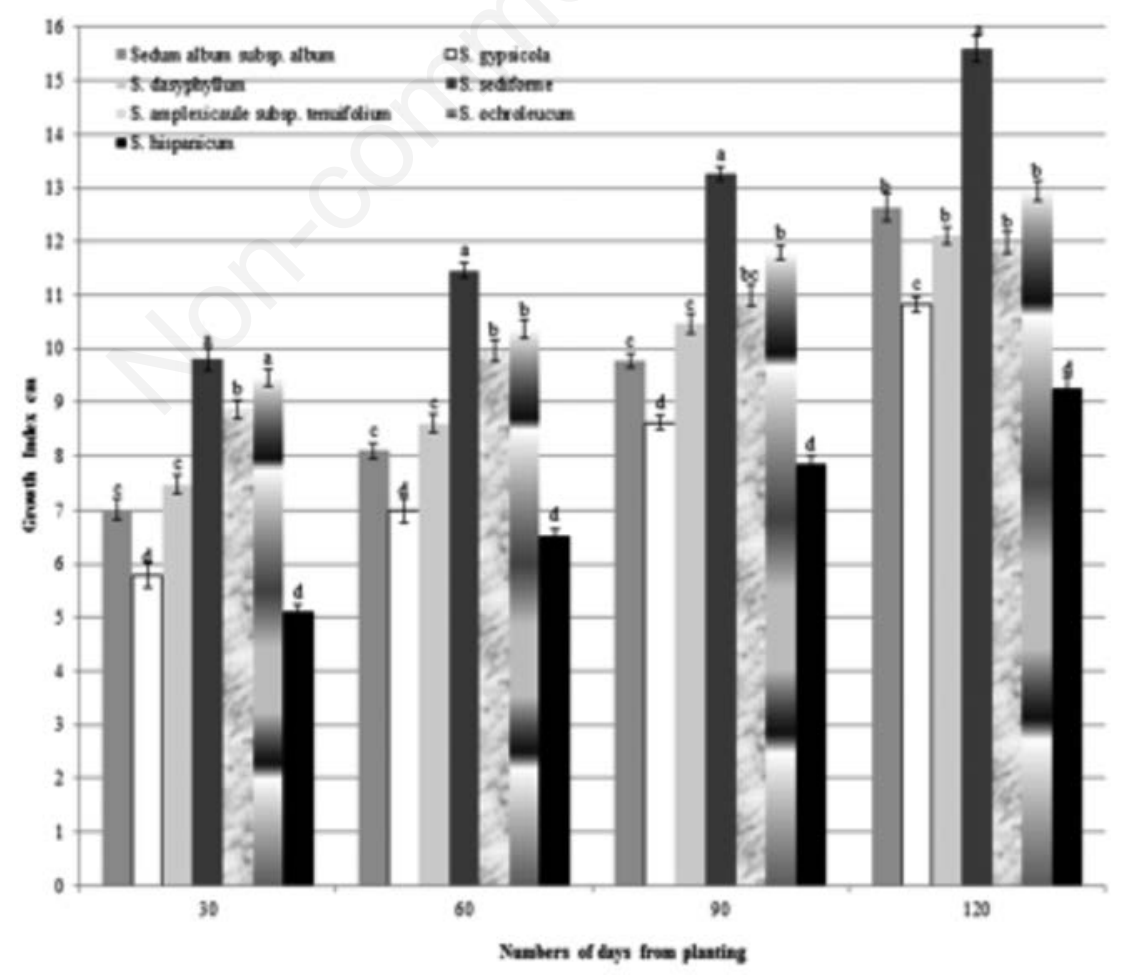

Figure 2. Plant growth index for Sedum perennial taxa. Values are means \pm SE. For each data, histograms with different letters are significantly different at $P \leq 0.01$, according to one-way ANOVA and separated using Tukey's test. 
album. Towards the end of the test period, however, ground cover results were the lowest for all the Sedum taxa $\left(160 \mathrm{~cm}^{2}\right)$, with the exception of $S$. hispanicum. Throughout the entire test period, ground cover results for $S$. hispanicum were the lowest (26.4 to $113 \mathrm{~cm}^{2}$ ) with statistically significant differences compared to all other Sedum entities. Finally, it is worth to note that taxa with the highest plant ground cover values showed also the highest growth index values. This highlights a relationship between the two parameters in the study.

\section{Conclusions}

The results of this study have led to greater understanding of Sicilian perennial Sedum entities of potential use in green roof systems in the Mediterranean. $12 \operatorname{taxa}$ were analysed in their habitat in order to obtain phenological and ecological data and were successfully planted in a open field collection at CREA Research Center. 7 of 12 taxa were considered more interesting for the aims of the study. These taxa were investigated in order to evaluate the rooting capacity, growth index and plant ground cover. The taxa respond particularly well to agamic propagation, with the exception of $S$. amplexicaule subsp. tenuifolium, with propagation percentage below $40 \%$. S. sediforme, S. album subsp. album, S. ochroleucum and $S$. hispanicum cuttings showed the best percentages already after 15 days from planting, reaching nearly $100 \%$ after only 30 days. These taxa show characteristics suited to nursery production of green roof systems. Growth indices and plant development demonstrated the capacity of a number of Sedum taxa to form a uniform green mantle over time. S. sediforme performed the best as regards growth index 120 days after planting (15.6), followed by S. ochroleucum (12.9), S. album (12.6), S. dasyphyllum var. dasyphyllum (12.1) and S. amplexicaule subsp. tenuifolium (12). On the contrary, the lowest growth indices were recorded with $S$. hyspanicum and $S$. gypsicola at 9.3 and 10.8 , respectively. In general, the results of plant growth index of this study are confirmed by several authors (Monterusso et al., 2005; Schaefer et al., 2005) who also investigated and observed other species and varieties of Sedum genus. In addition to plant growth index, this study also examined the average increase in plant ground cover: a parameter of fundamental importance for the establishment of the roof's green mantle. S. sediforme also performed best for this parameter over the entire observation period, ranging from $118 \mathrm{~cm}^{2}$ (after 30 days) to $300 \mathrm{~cm}^{2}$ (after 120 days). Results were also of interest regarding $S$. album and $S$. amplexicaule var. tenuifolium, with coverage of $242.6 \mathrm{~cm}^{2}$ and $202.3 \mathrm{~cm}^{2}$, respectively, 120 days. $S$. hyspanicum did not perform well regarding ground cover, both after 120 days $\left(113 \mathrm{~cm}^{2}\right)$ and over the entire observation period. These results highlights a relationship between the plant ground cover and growth index which are useful in order to evaluate the plant growth in its habitat. Based on results, moreover, not all plants belonging to the Sedum genus found in Sicily are suited for use in green roof systems. S. sediforme and S. album are of particular interest due to their good propagation capacity and their ability to colonize the substrate, and for this reason could be selected as fundamental components for the plant structure of new systems. However, there are also other plants, such as $S$. amplexicaule var. tenuifolium, and, to a lesser extent, $S$. dasyphyllum var. dasyphyllum and $S$. ochroleucum, which are able to contribute to floral diversification and lead to greater biodiversity in the system. These taxa could be used when creating associations of Sedum at lower

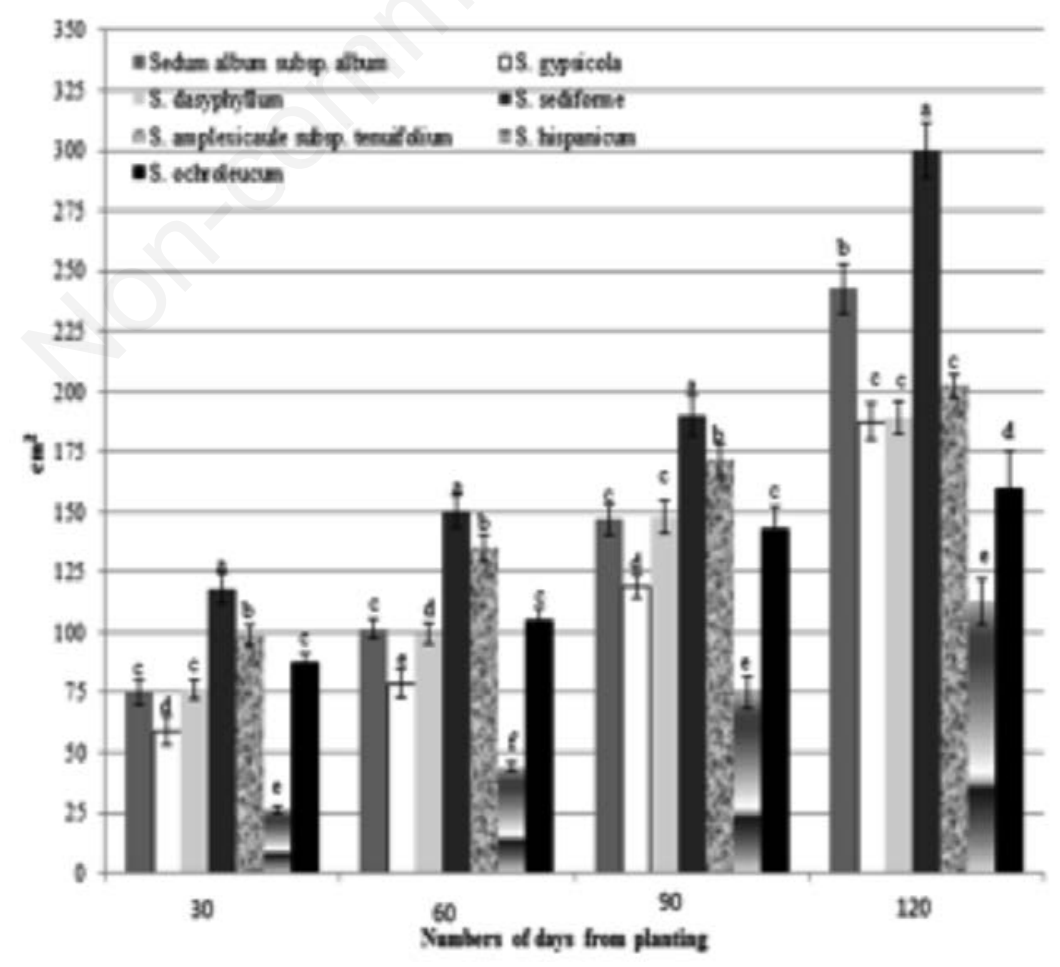

Figure 3. Mean increase in plant ground cover. Values are means \pm SE. For each data, histograms with different letters are significantly different at $P \leq 0.01$, according to one-way ANOVA and separated using Tukey's test. 
percentages compared to the structuring species $(\leq 20 \%)$. This study highlights, in addition to the hardiness of Sedum genus to tolerate a wide range of environmental conditions, that other growth indices are needed to obtain a fast plant ground cover.

\section{References}

Abram P, 2006. Verde pensile in Italia e in Europa. Il verde editoriale, pp. 24-31.

Benedict MA, McMahon ET, 2002. Green infrastructure: smart conservation for the $21^{\text {st }}$ century. Renew. Resour. 20:12-7.

Boivin M, Lamy M, Grosselin A, Dansereau B, 2001. Effect of artificial substrate depth on freezing injury of six herbaceous perennials grown in a green roof system. HortTechnol. 11:409. 12.

Carter JG, 2011. Climate change adaptation in European cities. Curr. Opin. Env. Sust. 3:193-8.

Conti F, Bonacquisti S, Abbate G, Alessandrini A, Blasi C, 2005. An annotated checklist of the Italian vascular flora. Palombi Editore, Roma, pp. 420.

Cushman JC, 2001. Crassulacean acid metabolism. A plastic photosynthetic adaptation to arid environments. Plant Physiol. 127:1439-48.

Dimoudi A, Nikolopoulou M, 2003. Vegetation in the urban environment: microclimatic analysis and benefits. Energ. Buildings 35:69-76.

Fioretti R, Palla A, Lanza LG, Principi P, 2010. Green roof energy and water related performance in the Mediterranean climate. Build. Environ. 45:1890-904.

Gómez-Campo C, 1994. Plantas para la naturación de azoteas:del género Sedum L. Agricultura (Espana) 749:1041-2.

Gómez-Campo C, Gómez-Tortosa L, 1996. Especies vegetale sen las azoteasverdes. Agricultura (Espana) 773:1029-31.

Gomez K.A., Gomez A.A., 1984. Statistical procedures for agricultural research. Ed. Wiley \& Sons, New York, pp. 306-308.

Grant G, Engleback, L, Nicholson B, 2003. Green roofs: existing status and potential for conserving biodiversity in urban areas. English Nature Research Report No. 498. Peterborough, U.K.: English Nature, pp. 12.

Gravatt D, 2003. Crassulacean acid metabolism and survival of asexual propagules of Sedum wrightii. Photosynthetica. 41:449-52.

Gravatt DA, Martin CE, 1992. Comparative ecophysiology of five species of Sedum (Crassulacae) under well-watered and drought-stressed conditions. Oecologia. 92:532-41.

Hart H, 1991. Evalution and classification of the European Sedum species. Fl. Medit. 1:31-61.

Heinz W, 1985. Results of an experiment on extensive growth of vegetation on roofs. Rasen Grunflachen Begrunungen 16:80-8.

Herman R, 2003. Green roofs in Germany: Yesterday, today and tomorrow. In Proceedings of the $1^{\text {st }}$ North American Green Roof Conf:: Greening Rooftops for Sustainable Communities, Chicago. 29-30 May 2003. The Cardinal Group, Toronto, Canada, pp. 41-45.

Kluge M, 1977. Is Sedum acre L. a CAM plant?. Oecologia. 29:7783.

Kluge M, Ting IP, 1978. Crassulacean acid metabolism. Analysis of an ecological adaptation. Ecol. Stud. 30:209.

Lassalle F, 1998. Wirkung von trockenstre $\beta$ auf xerophile pflanzen. Stadt und Grün. 47:437-43.

Lee KS, Kim JH, 1994. Changes in crassulacean acid metabolism
(CAM) of Sedum plants with special reference to soil moisture conditions. J. Plant Biol. 37:9-15.

Liesecke HJ, 1998. Das retentionsvermögen von dachbegrünungen. Stadt und Grün. 47:46-53.

Liesecke HJ, Borgwardt H, 1997. Abbau von luftschadstoffendurch extensive dachbegrunungen (Degradation of air pollutants by extensive green roofs). Stadt und Gru 46:245-51.

Liptan T, 2003. Planning, zoning and financial incentives for ecoroofs in Portland, Oregon. In Proceedings of the $1^{\text {st }}$ North American Green Roof Conf.: Greening Rooftops for Sustainable Communi- 3457-3464. ties, Chicago. 29-30 May 2003. The Cardinal Group, Toronto, Canada, pp. 113-120.

Mentens J, Raes D, Hermy M, 2003. Green roofs as a part of urban water management. In: Brebbia, C.A. (Ed.), Water Resources Management II. WIT Press, Southampton, UK, pp. 35-44.

Monterusso MA, Rowe DB, Rugh CL, 2005. Establishment and persistence of Sedum spp. and native taxa for green roof applications. HortSci. 40:391-6.

Niachou A, Papakonstantinou K, Santamouris M, Tsangrassouls A, Mihalakakou G, 2001. Analysis of the green roof thermal properties and investigation of its energy performance. Energ. Build. 33:719-29.

Osmundson T, 1999. Roof Gardens, History, Design, Construction. Norton \& Co., New York, USA.

Palla A, Gnecco I, Lanza LG, 2010. Hydrologic Restoration in the Urban Environment Using Green Roofs. Water 2:140-54.

Pignatti S, 1982. Flora d'Italia. Edagricole, Bologna, Italy.

Raimondo FM, Domina G, Spadaro V, 2010. Checklist of the vascular flora of Sicily. Quad. Bot. Amb. Appl. 21:189-252.

Razzaghmanesh M, Beecham S, Kazemi F, 2014. The growth and survival of plants in urban green roofs in a dry climate. Sci. Total Environ. 476-477:288-97.

Rowe DB, Rugh CL, Durhman AK, 2006. Assessment of substrate depth and composition on green roof plant performance Proceedings of the $4^{\text {th }}$ North American Green Roof Conference: Greening Rooftops for Sustainable Communities, 11-12 May, Boston, MA, USA.

Sayed OH, Earnshaw MJ, Cooper M, 1994. Growth, water relations, and CAM induction in Sedum album in response to water stress. Biol. Plant. 36:383-8.

Schaefer H, Forrester K, Jost V, Luckett K, Morgan S, Yan T, Retzlaff1 W, 2005. Effects of green roof growth medium depths on Sedum immergrauch establishment. ISAS Annual Meeting, April 2005, Chicago, IL, USA.

Terri JA, Turner M, Gurevitch J, 1986. The response of leaf water potential and crassulacean acid metabolism to prolonged drought in Sedum rubrotinctum. Plant Physiol. 81:678-80.

Troìa A, Pasta S, Campo G, Romano S, 1998. Indagini tassonomiche e corologiche sul genere Sedum L. serie Rupestria Berger (Crassulaceae) in Sicilia. Natur. Siciliano 4:73-85.

Van Mechelen C, Dutoit T, Hermy M, 2014. Mediterranean open habitat vegetation offers great potential for extensive green roof design. Landscape Urban Plan. 121:81-91.

VanWoert ND, Rowe DB, Andresen JA, Rugh CL, Xiao L, 2005. Watering regime and green roof substrate design affect Sedum plant growth. HortSci. 40:659-44.

Wong NH, Chen Y, Ong CL, Sia A, 2003. Investigation of thermal benefits of rooftop garden in the tropical environment. Build. Environ. 38:261-70.

Zinzi M, Agnoli S, 2012. Cool and green roofs. An energy and comfort comparison between passive cooling and mitigation urban heat island techniques for residential buildings in the Mediterranean region. Energ. Build. 55:66-76. 